\title{
An Improved Protocol for the Synthesis and Purification of Yariv Reagents
}

Raghuraj Hoshing, Michael Saladino, Helene Kuhn, David Caianiello, Robert F. Lusi, and Amit Basu*

Department of Chemistry, Brown University, Providence RI, USA 02912

abasu@brown.edu

\begin{abstract}
Yariv reagents are widely used tools to study plant proteoglycans known as the Arabinogalactan proteins (AGPs). Despite widespread use of the Yariv reagent in the study of AGPs and several reports of synthetic protocols, there remains a lack of a simple procedure to obtain pure Yariv reagents. We report our optimized protocols to address the purification issues faced upon synthesis of Yariv reagents. Additionally, we report challenges that make characterization difficult such as peak broadening in NMR due to Yariv-water interactions. We also show ways of processing Yariv reagents to overcome the characterization issues caused by peak broadening.
\end{abstract}




\section{Introduction}

Glycoconjugates are synthetic presentation of carbohydrates widely used in studies of carbohydrate recognition in biological systems. ${ }^{1}$ One of the earliest example of a glycoconjugate are the Yariv reagents (Figure 1), a set of tris-aryl glycoside azo dyes, first reported in 1962. (Yariv 1962). Several of these eponymous reagents are tools in plant biology. The $\beta$-D-glucopyranosyl and $\beta$-D-galactopyranosyl derivatives $\mathbf{1}$ and $\mathbf{2}$ are used to identify and isolate arabinogalactan proteins (AGPs). AGPs are branched proteoglycans found in plant cell walls and perform various cell signaling as well as structural support roles. ${ }^{2}$ Yariv reagents are primarily used for the histochemical staining ${ }^{3}$, quantification, ${ }^{4}$ and purification of AGPs. ${ }^{5} \mathbf{1}$ has also been used as a probe to elucidate the roles of AGPs in cellular physiology. ${ }^{6}$ Biophysical studies indicate that the Yariv reagents aggregate in solution and bind to the $\beta$ 1-3 galactans that comprise the backbone of AGPs.

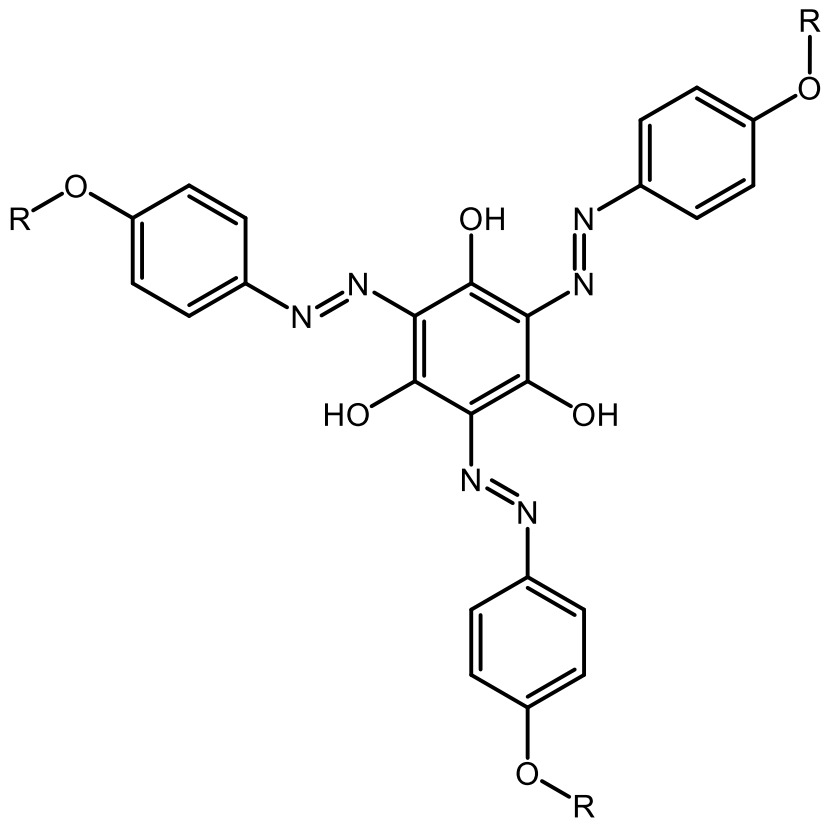

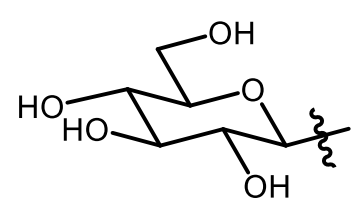

$1, R=\beta-D-G l u c o s y l$

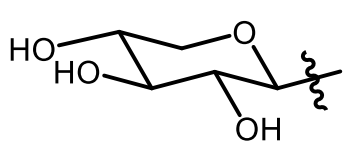

$3, R=\beta-D-X y l o s y l$

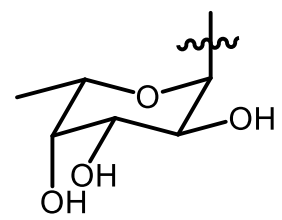

5, $R=\alpha-L-F u c o s y l$

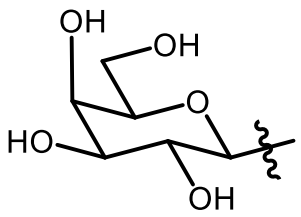

2, $R=\beta-D-$ Galactosyl

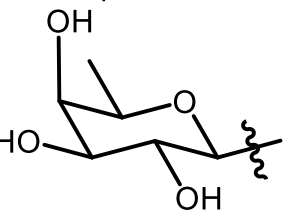

4, $R=\beta$-D-Fucosyl

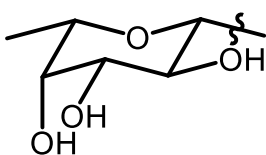

6, $R=\beta-L-F u c o s y l$

Figure 1 - The Yariv reagents

The Yariv reagents are synthesized by diazotization of the corresponding $p$-aminophenyl glycosides followed by coupling of the diazonium salt with phloroglucinol (Figure 2$).{ }^{7-11}$ In 
Yariv's original report, the dye was isolated from the coupling reaction by precipitation from ethanol. Several subsequent publications ${ }^{8,9}$ have reported additional synthetic details along with some minor modifications, but no new details of the isolation and purification protocols have appeared. Our own work as well as previous reports indicate that the isolated crude product can vary in its purity. ${ }^{12}$ The reported synthetic protocols provide limited details on further purification of the crude product. Furthermore, none of the Yariv reagents reported in the literature have accompanying complete NMR characterization data, perhaps due to these issues with purity - an incomplete list of ${ }^{1} \mathrm{H}$ NMR resonances has only been reported for only compounds $\mathbf{1}$ and $\mathbf{2} .{ }^{8,9}$

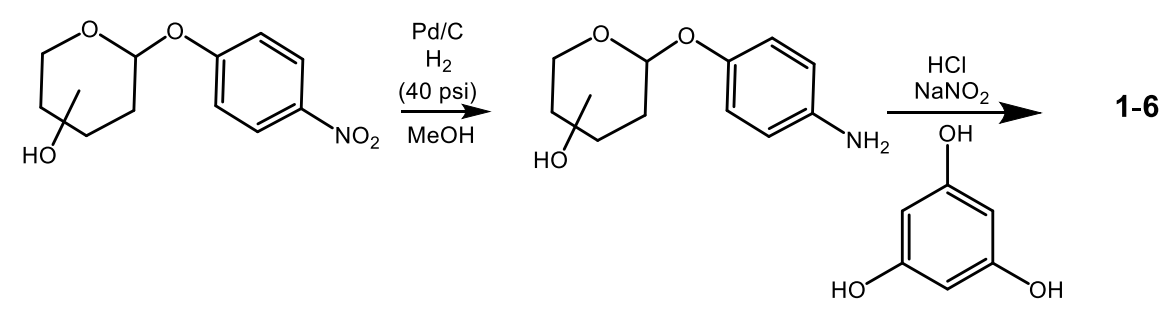

Figure 2 - General synthetic scheme for Yariv reagents

This lack of detail in purification protocols and characterization became very apparent during our syntheses of compounds $\mathbf{1}$ and $\mathbf{2}$ when we encountered variations in product purity and challenges in product characterization. In this report we describe a set of protocols that can be used to purify and characterize the Yariv reagents. We developed these protocols for the two 'canonical' Yariv reagents; $\beta$-D-Glc (1) and $\beta$-D-Gal Yariv (2). These optimized protocols were used to synthesize and purify several other Yariv reagents (3-6). Additionally, we also report the first complete spectral characterization data $(1 \mathrm{H}, 13 \mathrm{C}, \mathrm{COSY}, \mathrm{HSQC})$ for these Yariv reagents. 


\section{Results and Discussion}
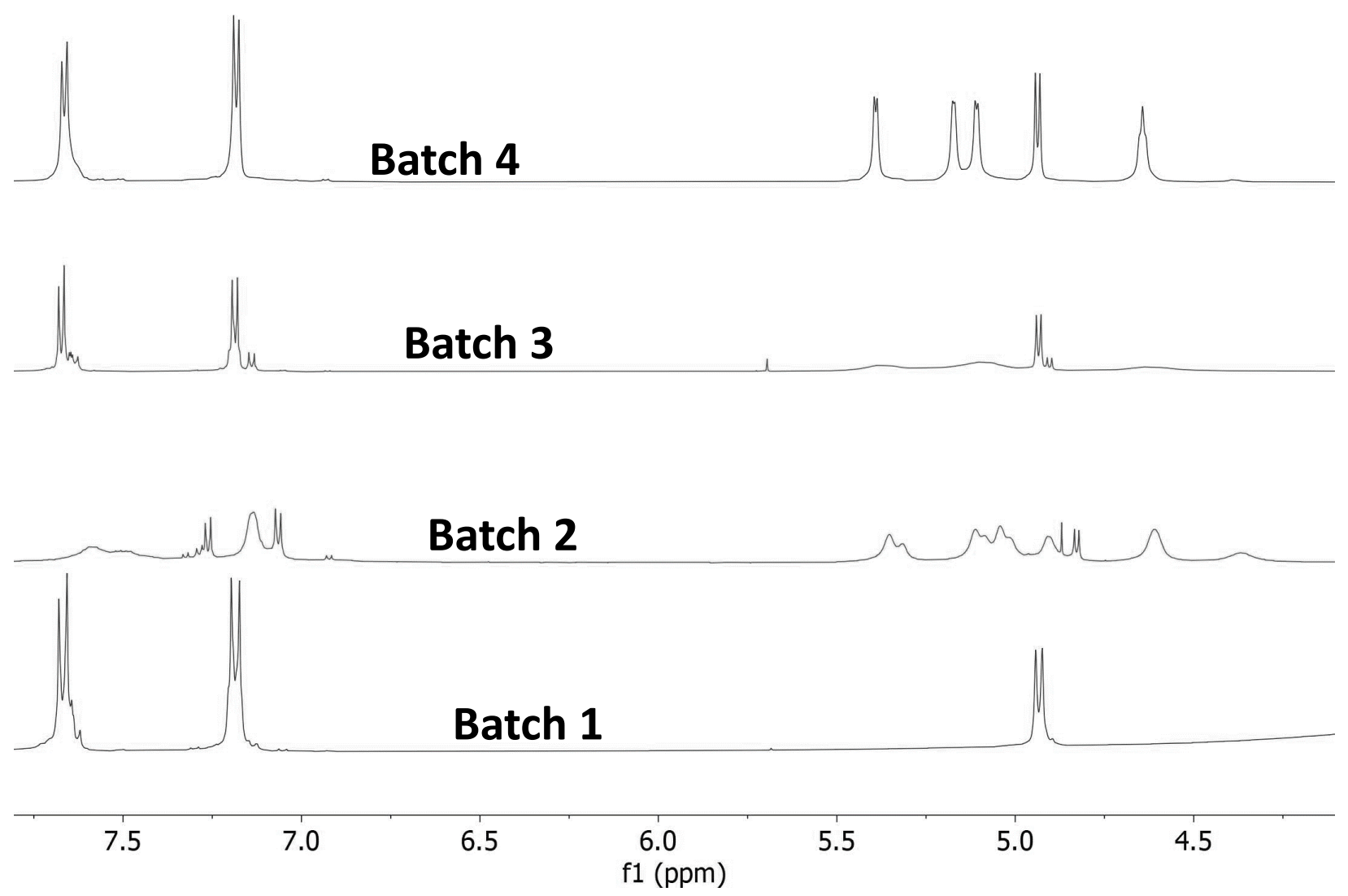

Figure 3 - NMR spectra of the crude product from multiple batches of $\beta$-D-Glc Yariv reagent

(1) syntheses

Multiple batches of $\beta$-D-Glc Yariv reagent (1) were synthesized using a slight modification of a literature protocol. ${ }^{9}$ The ${ }^{1} \mathrm{H}$ NMR spectra of the crude products of four representative batches are displayed in Figure 3, and exhibit a wide batch to batch variation in the purity and hydration of the crude materials. Resonances at 7.16 and $7.66 \mathrm{ppm}$ corresponding to the protons of the $p$ aminophenol moiety are clearly visible in each spectrum, but these resonances do not always appear as the expected sharp doublets (e.g batch 4). Several spectra exhibit additional peaks in the aromatic region, indicating the presence of impurities in these batches. Mass spectrometric analysis of the crude product of batch 2 indicates a signal at $\mathrm{m} / \mathrm{z}=691.1$, corresponding to the bis azo homologue, as previously suggested ${ }^{12}$ (Figure S1). Also observed in Figure 3 are variations in 
the peak shapes of the $-\mathrm{OH}$ resonances, with many, but not all, of these spectra exhibiting peak broadening from exchange with water especially for the sugar -OH resonances between 4.5 and $5.5 \mathrm{ppm}$.

Our attempts at removing the impurities focused on using the redissolution and reprecipitation protocol described by Woods et al. who observed increases in the molecular weight distribution of Yariv aggregates by analytical ultracentrifugation upon repeated redissolution of $\mathbf{1}$ in water followed by precipitation from methanol. ${ }^{12}$ They suggested that these impurities consisted of products derived from incomplete diazo coupling - i.e. bis- and/or mono- azo phloroglucinol derivatives, but additional characterization of purity was not provided. The NMR spectra of these reprecipitated products indicates that reprecipitation has significantly reduced the amount of impurities (Figure 4).
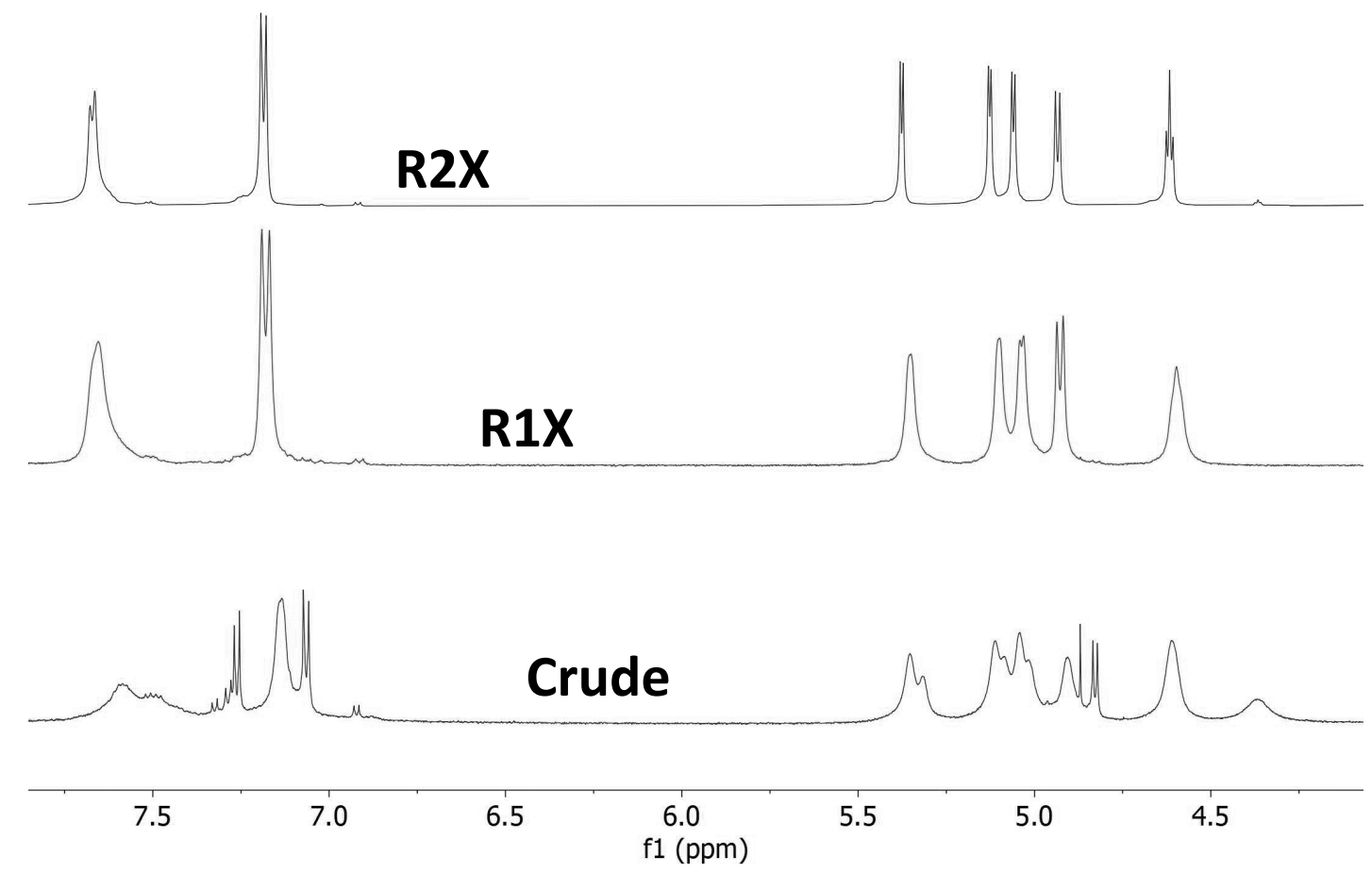

Figure 4 - Purification of (1) $\beta$-D-Glc Yariv batch 2 crude; Bottom to top: crude, reprecipitated once (R1X), reprecipitated twice (R2X) 
Figure 4 indicates the redissolution and reprecipitation process also results in a sharpening of the sugar $-\mathrm{OH}$ peaks after two rounds of purification. DOSY NMR experiments were carried out using two different samples of $\mathbf{1}$ - one exhibiting broad $-\mathrm{OH}$ resonances and the other exhibiting sharp peaks. The diffusion coefficient of the sugar $-\mathrm{OH}$ resonances is greater $(\log \mathrm{D}=$ $-5.9)$ in the samples containing broad peaks when compared to the sharp -OH peak samples $(\log$ $\mathrm{D}=-6.0$ ), indicating that the former peaks are diffusing faster. Moreover, the $\log \mathrm{D}$ values for the non-exchangeable protons of both samples such as the aromatic protons display the same constants $(\log \mathrm{D}=-6.1)$. These relative diffusion coefficient values are consistent with exchange of the sugar $\mathrm{OH}$ protons with water (Figure 5). Chemical exchange of the sugar -OH protons with water was also confirmed in the ROESY spectrum (SI). Examination of the level of trace water observed in the DMSO- $\mathrm{d}_{6}$ sample before and after dissolution of the Yariv reagent indicates an increase after analyte addition (Figure S9), establishing that the excess water observed in the NMR spectra originates from the Yariv reagent and not solely from trace moisture in the NMR solvent. Standard methods for removal of this extraneous water such as drying over $\mathrm{P}_{2} \mathrm{O}_{5}$ or Drierite under high vacuum were not successful. 


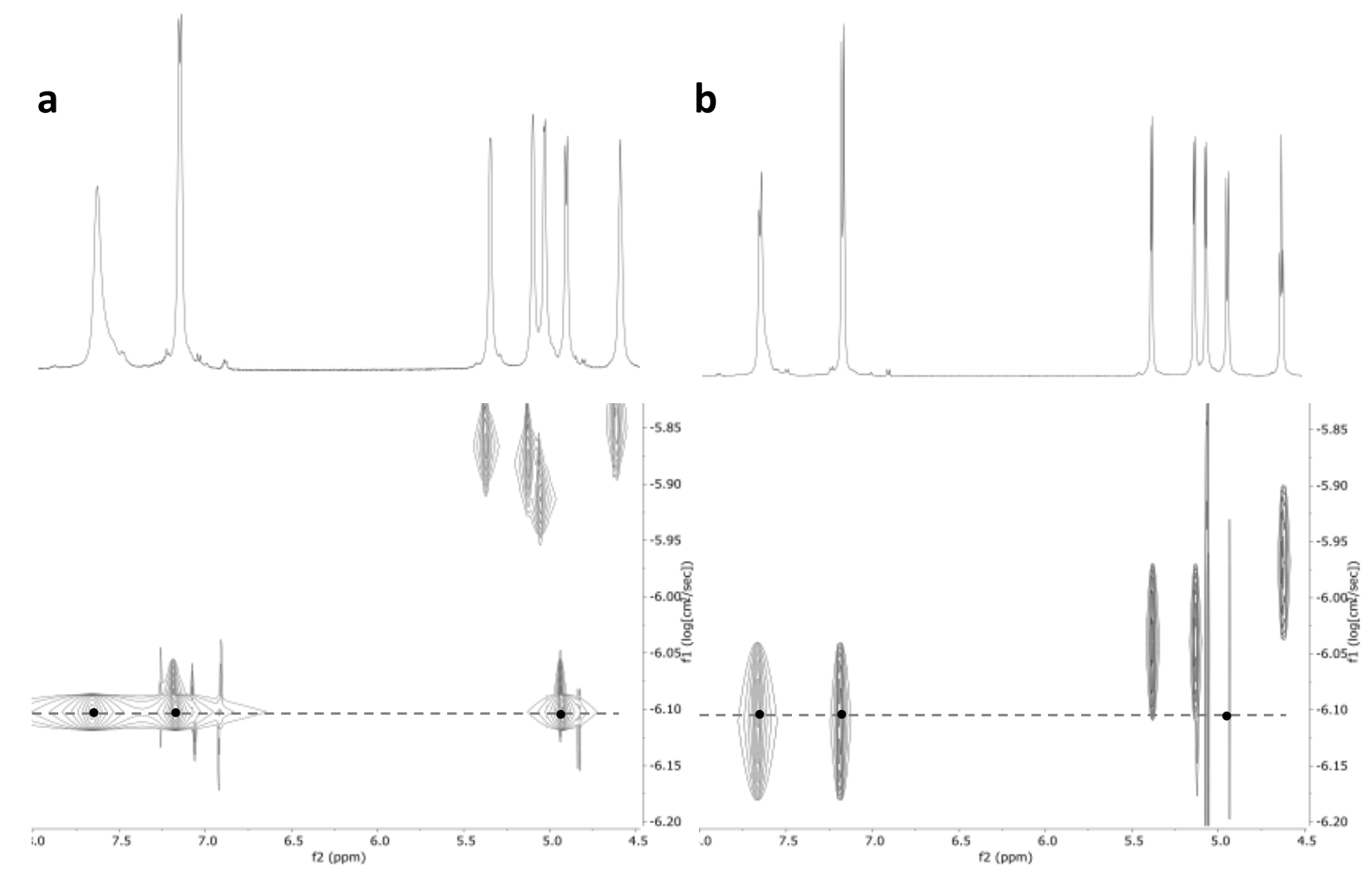

Figure 5 - Comparison of ${ }^{1} \mathrm{H}$ NMR and DOSY NMR spectra and of a (1) $\beta$ Dglc Yariv batch 2 sample containing (a) broad -OH peaks vs sample containing (b) sharp -OH peaks

Occasionally, additional processing was required to obtain sharp -OH peaks. For example, as seen in Figure 6, two rounds of redissolution and reprecipitation resolved individual -OH proton resonances that were not visible in the crude product, but these resonances remained broad. It was also frequently observed that trace amounts of ethanol would persist in these samples, despite prolonged drying attempts (Figure S10). We surmised that addition of methanol might help remove both residual water and ethanol, and might itself be easier to remove due to its lower boiling point. Trituration of $\mathbf{1}$ (batch 3) with boiling methanol, followed by filtration and subsequent drying in a vacuum oven successfully sharpened the $-\mathrm{OH}$ resonances (Figure 6). Besides sharpening $-\mathrm{OH}$ peaks, this process also effectively removes ethanol from the sample (Figure S10) with $80 \%$ of the triturated Yariv reagent recovered. 


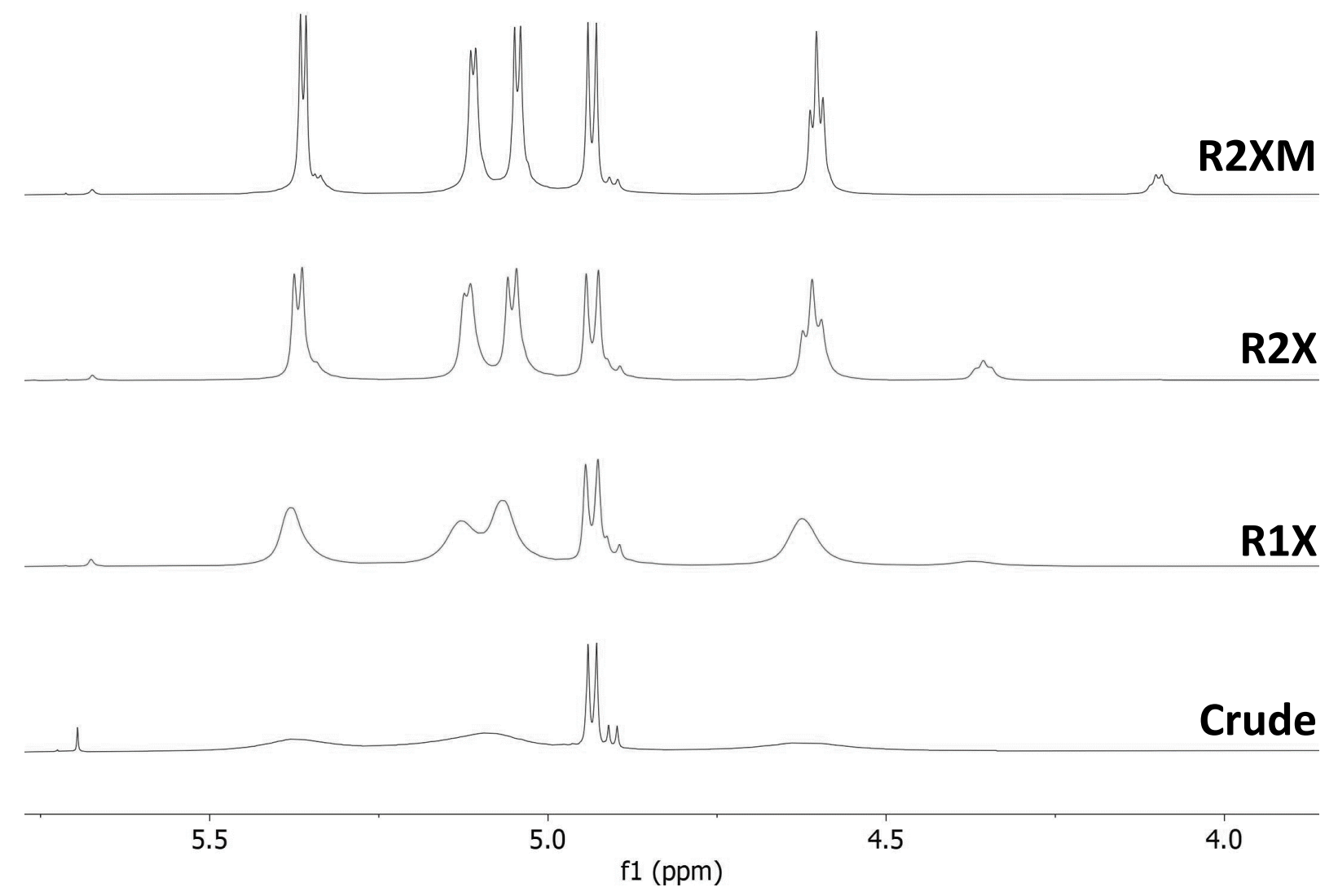

Figure 6 - From bottom to top: ${ }^{1} \mathrm{H}$ NMR of (1) $\beta$ DGlc Yariv batch 3 crude, first reprecipitation $(\mathrm{R} 1 \mathrm{X})$, second reprecipitation $(\mathrm{R} 2 \mathrm{X})$, triturated material (R2XM)

To highlight the utility of improved protocols, several other Yariv reagents (3-6), including the new $\beta$-D-fucosyl derivative 4 , were synthesized and purified using these optimized protocols. Several were known, but one is new (4). Several of the crude products exhibited significant $-\mathrm{OH}$ broadening (Figures S3 - S6). In each case, redissolution and reprecipitation effectively sharpened the $-\mathrm{OH}$ resonances. Reagents $\mathbf{3}, \mathbf{5}$, and $\mathbf{6}$ all exhibited the presence of significant amounts of ethanol even after this purification. The xylosyl analog 3 was triturated with methanol. The Lfucosyl compounds were rotary evaporated from methanol, a process that we have found to be as effective as trituration, with higher sample recovery when working at a smaller scale. Purified compounds were obtained in yields ranging from 40-85\% (Table S3) which are significantly higher 
than the $10 \%$ overall yield reported previously. ${ }^{12}$ All of these Yariv reagents were subsequently fully characterized by ${ }^{1} \mathrm{H}$ and ${ }^{13} \mathrm{C}$, HSQC and COSY NMR.

In summary, we present the various previously unaddressed issues with Yariv reagent synthesis, such as presence of lower homologue (bis/mono azo) impurities and broadening of sugar -OH NMR peaks due to exchange with water. We demonstrate that the Yariv reagents can be purified by a simple redissolution and reprecipitation process. We also show that the water-sugar $-\mathrm{OH}$ exchange and the presence of residual ethanol can be reduced by various treatments with methanol. An additional benefit of the protocols reported here is that they can potentially be used with glycoconjugates other than the Yariv reagents. It is worth noting here that many other amphiphilic glycoconjugates exhibit similar challenges with respect to resolving -OH resonances clearly, and in several cases where -OH resonances are well-resolved, the product was isolated from methanol. ${ }^{13-16}$ Finally, several additional Yariv reagents were synthesized, isolated and purified using the optimized procedures. These advances allowed full characterization of these Yariv reagents for the first time.

\section{Experimental Section}

\section{General Protocols:}

Thin layer chromatography was carried out on Merck silica gel $60 \mathrm{~F}_{254}$ precoated glass plates. Compounds were visualized under a UV lamp. All NMR spectra were recorded on Bruker Avance III HD Ascend $600 \mathrm{MHz}$ using deuterated DMSO as solvent. ${ }^{1} \mathrm{H}-\mathrm{NMR}$ and ${ }^{13} \mathrm{C}-\mathrm{NMR}$ spectra were referenced to residual solvent peaks. Coupling constants are given in $[\mathrm{Hz}]$ and chemical shifts in [ppm]. Electrospray ionization (ESI) mass spectra were obtained using a Thermo LCQ Deca XP Max ion trap mass spectrometer. Purified water was obtained from a EMD Millipore Direct- $\mathrm{Q}^{\mathrm{TM}}$ 3 Tap to Pure and Ultrapure Water Purification System. 


\section{Redissolution - reprecipitation representative protocol}

To $0.6 \mathrm{~g}$ of the crude product ( $\beta \mathrm{glc}$ batch 4$), 20 \mathrm{~mL}$ of water was added, the mixture was heated and vortexed until complete dissolution. $130 \mathrm{~mL}$ of cold $100 \%$ ethanol was added to the solution. The mixture was filtered through a Hirsch funnel and the precipitate was allowed to air dry and then transferred to a pre weighed vial. The precipitate was then allowed to dry in a vacuum oven overnight. $0.5 \mathrm{~g}$ of materiel was obtained.

\section{Methovaping representative protocol}

$10 \mathrm{mg}$ of $\beta$ Glc batch 1 was weighed out into a scintillation vial. $3 \mathrm{~mL}$ of methanol was added to the vial and then evaporated using a rotovap. The vial was allowed to sit without a cap in a dessicator containing Dririte ${ }^{\mathrm{TM}}$ for three days.

\section{Trituration representative protocol}

$0.19 \mathrm{~g}$ of the $\beta$ Glc batch $4 \mathrm{R} 2 \mathrm{X}$ was weighed out into an Erlenmeyer flask. The materiel was then rinsed with $10 \mathrm{~mL}$ of boiling methanol 5 times and filtered through a Hirsch funnel. It was then dried in a vacuum oven overnight. $0.18 \mathrm{~g}$ of materiel was obtained.

\section{Synthesis of $\beta$-D-Glucosyl Yariv reagent (1)}

A Parr shaker bottle was charged with 4-nitrophenyl $\beta$-D-glucopyranoside (2.5 g, $8.3 \mathrm{mmol})$ and methanol $(250 \mathrm{~mL})$ and a stir bar were added to the bottle. The mixture was stirred while sparging for 20 minutes with $\mathrm{N}_{2}$ introduced via a needle. $10 \% \mathrm{Pd} / \mathrm{C}$ (40 mg) was added to the Parr bottle, which was put on a Parr shaker and shaken under $40 \mathrm{psi} \mathrm{H}_{2}$ for 7 hours. TLC showed complete conversion (2:1 Dichloromethane /Isopropyl alcohol). The solution was then filtered through Celite into a $1000 \mathrm{~mL}$ flask and then concentrated in vacuo to about $100 \mathrm{~mL}$. Solution was transferred into a $250 \mathrm{~mL}$ preweighed flask and concentrated in vacuo and placed under high vacuum. The amino sugar was obtained as a pale yellow/clear crystalline solid $(2.20 \mathrm{~g}, 8.1$ mmol, $97 \%$ ). This material was directly used in the next step. ${ }^{1} \mathrm{H}$ NMR (600 MHz, DMSO- $\left.d_{6}\right) \delta$ $6.77(\mathrm{~d}, 2 \mathrm{H}), 6.49(\mathrm{~d}, 2 \mathrm{H}), 5.23(\mathrm{~d}, 1 \mathrm{H}), 5.07(\mathrm{~d}, J=4.6 \mathrm{~Hz}, 1 \mathrm{H}), 5.00(\mathrm{~d}, J=4.9 \mathrm{~Hz}, 1 \mathrm{H}), 4.69$ $(\mathrm{s}, 2 \mathrm{H}), 4.57(\mathrm{~d}, 1 \mathrm{H}), 4.55(\mathrm{t}, 1 \mathrm{H}), 3.71-3.65(\mathrm{~m}, 1 \mathrm{H}), 3.46(\mathrm{dt}, J=11.5,5.4 \mathrm{~Hz}, 1 \mathrm{H}), 3.25-$ 3.09 (m, 6H). 
A solution of cold freshly prepared $1.2 \mathrm{M} \mathrm{HCl}(17 \mathrm{~mL}, 2.5$ eq, made by adding $3 \mathrm{~mL}$ of $12.1 \mathrm{M}$ $\mathrm{HCl}$ to $27 \mathrm{~mL}$ of water) was added to 4-aminophenyl $\beta$-D-glucopyranoside ${ }^{17}(2.2 \mathrm{~g}, 8.11 \mathrm{mmol}$, $1 \mathrm{eq})$ in a $250 \mathrm{~mL}$ round bottom flask. This solution was cooled in an ice bath while stirring. A solution of $\mathrm{NaNO}_{2}(616 \mathrm{mg}, 8.9 \mathrm{mmol}, 1.1 \mathrm{eq})$ dissolved in $1 \mathrm{~mL}$ of cold water in an Eppendorf tube was added to a $5 \mathrm{~mL}$ syringe with a 4 inch $\mathrm{x} 22$ gauge needle which was clamped above the reaction flask, leading to a gravity assisted dropwise addition. The reaction was stirred at $0{ }^{\circ} \mathrm{C}$ for $3 \mathrm{hrs}$. Phloroglucinol (348 mg, $2.8 \mathrm{mmol}, 0.34 \mathrm{eq}$ ) was dissolved in a minimal amount of cold $5 \mathrm{M} \mathrm{NaOH}(1 \sim 2 \mathrm{ml})$ and added dropwise to the reaction. $5 \mathrm{M} \mathrm{NaOH}$ was added until the $\mathrm{pH}$ was basic as indicated by $\mathrm{pH}$ paper, at which point the ice bath was removed. The $\mathrm{pH}$ was maintained at $\sim 11$ (dark blue on $\mathrm{pH}$ strip) by addition of $5 \mathrm{M} \mathrm{NaOH}$ as necessary. The reaction was allowed to stir overnight. Cold $100 \%$ ethanol $(200 \mathrm{~mL})$ was added to the reaction, which was neutral at this point, as determined by $\mathrm{pH}$ paper. $1.2 \mathrm{M} \mathrm{HCl}$ was added until the solution was acidic as indicated by $\mathrm{pH}$ paper. The reactions flask was placed in a freezer for at least 24 hours until a dark red/brown precipitate was observed. The precipitate was filtered through a Hirsch funnel to provide the crude Yariv reagent $\mathbf{1}$ as a glossy red, sticky powder which clumped together. This solid was allowed to air dry for a few hours, at which point it had hardened in to a solid mass which became a powder when crushed. The powder was transferred to a pre-weighed scintillation vial and dried in a vacuum oven with heat on at a low setting for 24 hours. This crude product ( $2.31 \mathrm{~g}, 2.4 \mathrm{mmol}$ ), was obtained in $86 \%$ yield. Some of this material was further purified twice using the redissolution - reprecipitation protocol followed by trituration using the general protocols reported in the SI: $0.6 \mathrm{~g}$ of the crude product was reprecipitated to give $0.5 \mathrm{~g}$ of $\beta$ Glc batch 4 R1X product (81\%). The second redissolution - reprecipitation with R1X (0.4 g) provided $0.35 \mathrm{~g}$ of $\beta \mathrm{Glc}$ batch $4 \mathrm{R} 2 \mathrm{X}$ (85\%). $0.19 \mathrm{~g}$ of the $\beta \mathrm{Glc}$ batch $4 \mathrm{R} 2 \mathrm{X}$ was then triturated to afford $0.18 \mathrm{~g}$ of $\beta$ Glc batch 4 R2XM 8 (95\%) ${ }^{1} \mathrm{H}$ NMR (600 MHz, DMSO) $\delta$ 15.91-15.90, 15.11 and $15.06(\mathrm{~s}, 3 \mathrm{H}), 7.66(\mathrm{~d}, J=8.6 \mathrm{~Hz}, 6 \mathrm{H}), 7.18(\mathrm{~d}, J=8.7 \mathrm{~Hz}, 6 \mathrm{H}), 5.37(\mathrm{~d}, J=5.0 \mathrm{~Hz}$, $3 \mathrm{H}), 5.11(\mathrm{~d}, J=4.7 \mathrm{~Hz}, 3 \mathrm{H}), 5.05(\mathrm{~d}, J=5.3 \mathrm{~Hz}, 1 \mathrm{H}), 4.94(\mathrm{~d}, J=7.4 \mathrm{~Hz}, 1 \mathrm{H}), 4.61(\mathrm{t}, J=5.8$ $\mathrm{Hz}, 3 \mathrm{H}), 3.73$ (m, $J=12.0,5.3,2.1 \mathrm{~Hz}, 3 \mathrm{H}), 3.50$ (m, $J=11.9,6.0 \mathrm{~Hz}, 3 \mathrm{H}), 3.38$ (m, $J=9.7$, 5.7, $2.3 \mathrm{~Hz}, 3 \mathrm{H}), 3.34-3.23(\mathrm{~m}, 6 \mathrm{H}), 3.19(\mathrm{~m}, J=9.0,4.9 \mathrm{~Hz}, 3 \mathrm{H}) .{ }^{13} \mathrm{C} \mathrm{NMR}(151 \mathrm{MHz}$, DMSO) $\delta 178.13,156.82,136.55,128.90,118.95,117.98,100.97,77.59,77.07,73.72,70.16$, 61.17 


\section{Synthesis of $\beta$-D-Galactosyl Yariv reagent (2)}

A Parr shaker bottle was charged with 4-nitrophenyl $\beta$-D-galactopyranoside (1 g, $3.3 \mathrm{mmol})$ and methanol $(250 \mathrm{~mL})$ and a stir bar were added to the bottle. The mixture was stirred while sparging for 20 minutes with $\mathrm{N}_{2}$ introduced via a needle. $10 \% \mathrm{Pd} / \mathrm{C}(35 \mathrm{mg}$ ) was added to the Parr bottle, which was put on a Parr shaker and shaken under $40 \mathrm{psi}_{2}$ for 7 hours. TLC showed complete conversion (5:1 Dichloromethane /Methanol). The product was dried in vacuo overnight to give the aniline as a pale-yellow powder $(0.8 \mathrm{~g}, 2.8 \mathrm{mmol}, 85 \%)$. This material was directly used in the next step. 1H NMR (600 MHz, DMSO- $\left.d_{6}\right) \delta 6.75(\mathrm{~d}, \mathrm{~J}=8.7 \mathrm{~Hz}, 2 \mathrm{H}), 6.47$ $(\mathrm{d}, \mathrm{J}=8.7 \mathrm{~Hz}, 2 \mathrm{H}), 5.05(\mathrm{~d}, \mathrm{~J}=4.9 \mathrm{~Hz}, 1 \mathrm{H}), 4.78(\mathrm{~d}, \mathrm{~J}=5.6 \mathrm{~Hz}, 1 \mathrm{H}), 4.67(\mathrm{~s}, 2 \mathrm{H}), 4.60(\mathrm{t}, \mathrm{J}=$ $5.4 \mathrm{~Hz}, 1 \mathrm{H}), 4.53(\mathrm{~d}, \mathrm{~J}=7.7 \mathrm{~Hz}, 1 \mathrm{H}), 4.43(\mathrm{~d}, \mathrm{~J}=4.6 \mathrm{~Hz}, 1 \mathrm{H}), 3.66(\mathrm{t}, \mathrm{J}=3.9 \mathrm{~Hz}, 1 \mathrm{H}), 3.60-$ $3.51(\mathrm{~m}, 1 \mathrm{H}), 3.51-3.41(\mathrm{~m}, 3 \mathrm{H}), 3.37-3.33(\mathrm{~m}, 1 \mathrm{H})$.

A solution of cold freshly prepared $2.4 \mathrm{M} \mathrm{HCl}(2.5 \mathrm{~mL}, 2.5 \mathrm{eq})$ was added to 4-aminophenyl $\beta$ D-galactopyranoside ${ }^{17}(584 \mathrm{mg}, 2.15 \mathrm{mmol}, 1 \mathrm{eq})$ in a $250 \mathrm{~mL}$ round bottom flask. This solution was cooled in an ice bath while stirring. A solution of $\mathrm{NaNO}_{2}(164 \mathrm{mg}, 2.4 \mathrm{mmol}, 1.1 \mathrm{eq})$ dissolved in $0.3 \mathrm{~mL}$ of cold water in an Eppendorf tube was added to a $1 \mathrm{~mL}$ syringe with a 4 inch $\mathrm{x} 22$ gauge needle which was clamped above the reaction flask, leading to a gravity assisted dropwise addition. The reaction was stirred at $0{ }^{\circ} \mathrm{C}$ for $3 \mathrm{hrs}$. Phloroglucinol $(93 \mathrm{mg}, 0.7 \mathrm{mmol}$, 0.34 eq) was dissolved in a minimal amount of cold $2 \mathrm{M} \mathrm{NaOH}(1 \sim 2 \mathrm{ml})$ ) and added dropwise to the reaction. $2 \mathrm{M} \mathrm{NaOH}$ was added until the $\mathrm{pH}$ was basic as indicated by $\mathrm{pH}$ paper, at which point the ice bath was removed. The $\mathrm{pH}$ was maintained at $\sim 11$ (dark blue on $\mathrm{pH}$ strip) by addition of $2 \mathrm{M} \mathrm{NaOH}$ as necessary. The reaction was allowed to stir for five hours. Cold $100 \%$ ethanol $(200 \mathrm{~mL})$ was added to the reaction, which was $\mathrm{pH} 6$ at this point, as determined by $\mathrm{pH}$ paper. The reactions flask was placed in a freezer for at least 24 hours until a dark red/brown precipitate was observed. The precipitate was filtered through a Hirsch funnel to provide the crude Yariv reagent 2 as a glossy red, sticky powder which clumped together. This solid was allowed to air dry for a few hours, at which point it had hardened in to a solid mass which became a powder when crushed. The powder was transferred to a pre-weighed scintillation vial and dried in a vacuum oven with heat on at a low setting for 1 hour. This crude product $(0.6 \mathrm{~g}$, $0.63 \mathrm{mmol}$ ), was obtained in $87 \%$ yield. Some of this material was further purified twice using trituration protocol as reported in the general protocols, followed by the redissolution - 
reprecipitation protocol twice with a slight modification, a small amount of product was dissolved in $1 \mathrm{~mL}$ of water and ethanol was added until product precipitated $(\sim 1 \mathrm{~mL}) .{ }^{1} \mathrm{H} \mathrm{NMR}$ (600 MHz, DMSO) $\delta 15.93(\mathrm{~s}, 3 \mathrm{H}), 7.65(\mathrm{~d}, 6 \mathrm{H}), 7.18$ (d, $J=8.7 \mathrm{~Hz}, 6 \mathrm{H}), 5.21(\mathrm{~d}, J=5.2 \mathrm{~Hz}$, $3 \mathrm{H}), 4.90$ (d, 3H), 4.88 (d, 3H), 4.69 (t, $J=5.4 \mathrm{~Hz}, 3 \mathrm{H}), 4.53$ (d, $J=4.6 \mathrm{~Hz}, 3 \mathrm{H}), 3.72(\mathrm{t}, J=4.2$ $\mathrm{Hz}, 3 \mathrm{H}), 3.66-3.49(\mathrm{~m}, 12 \mathrm{H}), 3.44(\mathrm{~m}, J=9.1,5.3,2.2 \mathrm{~Hz}, 3 \mathrm{H})$.

\section{Synthesis of $\beta$-D-Xylosyl Yariv reagent (3)}

A Parr shaker bottle was charged with 4-nitrophenyl $\beta$-D-xylopyranoside (1.0 g, $3.7 \mathrm{mmol})$ and methanol $(250 \mathrm{~mL})$ and a stir bar were added to the bottle. The mixture was stirred while sparging for 20 minutes with $\mathrm{N}_{2}$ introduced via a needle. $10 \% \mathrm{Pd} / \mathrm{C}(36 \mathrm{mg})$ was added to the Parr bottle, which was put on a Parr shaker and shaken under 40 psi $\mathrm{H}_{2}$ for 7 hours. TLC showed complete conversion (2:1 Dichloromethane/Isopropyl alcohol). The solution was then filtered through Celite into a $1000 \mathrm{~mL}$ flask and then concentrated in vacuo to about $75 \mathrm{~mL}$ and transferred into a $250 \mathrm{~mL}$ preweighed flask and concentrated in vacuo and placed under high vacuum. The amino sugar was obtained as a pale yellow/clear crystalline solid ( $0.9 \mathrm{~g}, 3.6 \mathrm{mmol}$, $97 \%$ ). This material was directly used in the next step. ${ }^{1} \mathrm{H}$ NMR (600 MHz, DMSO) $\delta 6.72$ (d, $2 \mathrm{H}), 6.49(\mathrm{~d}, 2 \mathrm{H}), 5.26(\mathrm{~d}, 1 \mathrm{H}), 5.10(\mathrm{~d}, 1 \mathrm{H}), 5.04(\mathrm{~d}, 1 \mathrm{H}), 4.70(\mathrm{~s}, 2 \mathrm{H}), 4.56(\mathrm{~d}, J=7.2 \mathrm{~Hz}, 1 \mathrm{H})$, $3.70(\mathrm{dd}, J=11.2,5.3 \mathrm{~Hz}, 1 \mathrm{H}), 3.22-3.08(\mathrm{~m}, 3 \mathrm{H})$.

A solution of cold freshly prepared $1.2 \mathrm{M} \mathrm{HCl}(8 \mathrm{~mL}, 2.5 \mathrm{eq}$, made by adding $3 \mathrm{~mL}$ of $12.1 \mathrm{M}$ $\mathrm{HCl}$ to $27 \mathrm{~mL}$ of water) was added to 4 -aminophenyl $\beta$-D-xylopyranoside ${ }^{18}(0.89 \mathrm{~g}, 3.7 \mathrm{mmol}, 1$ eq) in a $250 \mathrm{~mL}$ round bottom flask. This solution was cooled in an ice bath while stirring. A solution of $\mathrm{NaNO}_{2}(281 \mathrm{mg}, 4.1 \mathrm{mmol}, 1.1 \mathrm{eq})$ dissolved in $1 \mathrm{~mL}$ of cold water in an Eppendorf tube was added to a $5 \mathrm{~mL}$ syringe with a 4 inch $\mathrm{x} 22$ gauge needle which was clamped above the reaction flask, leading to a gravity assisted dropwise addition. The reaction was stirred at $0{ }^{\circ} \mathrm{C}$ for $3 \mathrm{hrs}$. Phloroglucinol (159 mg, $1.3 \mathrm{mmol}, 0.34 \mathrm{eq}$ ) was dissolved in a minimal amount of cold $2 \mathrm{M} \mathrm{NaOH}(1 \sim 2 \mathrm{ml}))$ and added dropwise to the reaction. $2 \mathrm{M} \mathrm{NaOH}$ was added until the $\mathrm{pH}$ was basic as indicated by $\mathrm{pH}$ paper, at which point the ice bath was removed. The $\mathrm{pH}$ was maintained at $\sim 11$ (dark blue on $\mathrm{pH}$ strip) by addition of $2 \mathrm{M} \mathrm{NaOH}$ as necessary. The reaction was allowed to stir overnight. Cold $100 \%$ ethanol $(150 \mathrm{~mL})$ was added to the reaction, which was neutral at this point, as determined by $\mathrm{pH}$ paper. $1.2 \mathrm{M} \mathrm{HCl}$ was added until the solution was 
acidic as indicated by $\mathrm{pH}$ paper. The reactions flask was placed in a freezer for at least 24 hours until a dark red/brown precipitate was observed. The precipitate was filtered through a Hirsch funnel to provide the crude Yariv reagent $\mathbf{3}$ as a glossy red, sticky powder which clumped together. This solid was allowed to air dry for a few hours, at which point it had hardened in to a solid mass which became a powder when crushed. The powder was transferred to a pre-weighed scintillation vial and dried in a vacuum oven with heat on at a low setting for 24 hours. This crude product ( $0.84 \mathrm{~g}, 0.9 \mathrm{mmol}$ ), was obtained in $77 \%$ yield. This material was further purified twice using the redissolution - reprecipitation protocol followed by trituration and methovaping using the general protocols reported in the SI: $0.8 \mathrm{~g}$ of the crude product was reprecipitated from $30 \mathrm{~mL}$ of water and $80 \mathrm{~mL}$ of ethanol to give $0.45 \mathrm{~g}$ of $\beta \mathrm{DXyl} \mathrm{R} 1 \mathrm{X}$ product (53\%). The second redissolution - reprecipitation with R1X $(0.45 \mathrm{~g})$ reprecipitated from $30 \mathrm{~mL}$ of water and $80 \mathrm{~mL}$ of ethanol provided $0.36 \mathrm{~g}$ of $\beta \mathrm{DXyl}$ R2X (82\%). $0.36 \mathrm{~g}$ of the of $\beta \mathrm{DXyl} \mathrm{R} 2 \mathrm{X}$ was then triturated to afford $0.33 \mathrm{~g}$ of of $\beta \mathrm{DXyl}$ R2XM (92\%). $0.037 \mathrm{~g}$ of $\beta \mathrm{DXyl}$ R2XM sample was methovaped using $3 \mathrm{~mL}$ of MeOH to give $0.033 \mathrm{~g}$ of $\beta \mathrm{DXyl} \mathrm{R} 2 \mathrm{XM} 2(90 \%) .{ }^{1} \mathrm{H}$ NMR (600 MHz, DMSO) $\delta$ 15.91, 15.86, 15.09 and 15.05 (s, 3H), $7.64(\mathrm{~d}, J=8.7 \mathrm{~Hz}, 6 \mathrm{H}), 7.15$ (d, $J=8.5 \mathrm{~Hz}, 6 \mathrm{H}), 5.40$ (d, $J=3.8 \mathrm{~Hz}, 3 \mathrm{H}), 5.14$ (d, 3H), $5.10(\mathrm{~d}, J=4.6 \mathrm{~Hz}, 3 \mathrm{H}), 4.94(\mathrm{~d}, J=6.3 \mathrm{~Hz}, 3 \mathrm{H}), 3.79$ (dd, $J=$ 10.9, $5.1 \mathrm{~Hz}, 3 \mathrm{H}), 3.40$ (m, $J=9.1,4.3 \mathrm{~Hz}, 3 \mathrm{H}), 3.32(\mathrm{~m}, J=10.9 \mathrm{~Hz}, 3 \mathrm{H}), 3.27(\mathrm{~m}, 6 \mathrm{H}) .{ }^{13} \mathrm{C}$ NMR (151 MHz, DMSO) $\delta 178.11,156.54,136.59,128.88,118.97,118.02,101.48,76.88$, $73.54,69.81,66.24$

\section{Synthesis of $\beta$-D-Fucosyl Yariv reagent (4)}

A Parr shaker bottle was charged with 4-nitrophenyl $\beta$-D-fucopyranoside $(0.5 \mathrm{~g}, 1.7 \mathrm{mmol})$ and methanol $(250 \mathrm{~mL})$ and a stir bar were added to the bottle. The mixture was stirred while sparging for 20 minutes with $\mathrm{N}_{2}$ introduced via a needle. $10 \% \mathrm{Pd} / \mathrm{C}(37 \mathrm{mg})$ was added to the Parr bottle, which was put on a Parr shaker and shaken under $40 \mathrm{psi}_{2}$ for 7 hours. TLC showed complete conversion (2:1 Dichloromethane /Isopropyl alcohol). The solution was then filtered through Celite into a $1000 \mathrm{~mL}$ flask and then concentrated in vacuo to about $100 \mathrm{~mL}$ and transferred into a $250 \mathrm{~mL}$ preweighed flask and concentrated in vacuo and placed under high vacuum. The amino sugar was obtained as a pale yellow/clear crystalline solid $(0.4 \mathrm{~g}, 1.6 \mathrm{mmol}$, $99 \%$ ). This material was directly used in the next step. ${ }^{1} \mathrm{H}$ NMR (600 MHz, DMSO) $\delta 6.72$ (d, 
2H), $6.48(\mathrm{~d}, 2 \mathrm{H}), 5.06(\mathrm{~d}, 1 \mathrm{H}), 4.85(\mathrm{~d}, 1 \mathrm{H}), 4.67(\mathrm{~s}, 2 \mathrm{H}), 4.55(\mathrm{~d}, J=7.6 \mathrm{~Hz}, 1 \mathrm{H}), 3.63(\mathrm{q}, J=$ $6.6 \mathrm{~Hz}, 1 \mathrm{H}), 3.49-3.40(\mathrm{~m}, 2 \mathrm{H}), 3.40-3.28(\mathrm{~m}, 2 \mathrm{H}), 1.13(\mathrm{~d}, J=6.4 \mathrm{~Hz}, 3 \mathrm{H})$.

A solution of cold freshly prepared $1.2 \mathrm{M} \mathrm{HCl}(4 \mathrm{~mL}, 2.5 \mathrm{eq}$, made by adding $3 \mathrm{~mL}$ of $12.1 \mathrm{M}$ $\mathrm{HCl}$ to $27 \mathrm{~mL}$ of water) was added to 4-aminophenyl $\beta$-D-fucopyranoside ${ }^{18}(0.4 \mathrm{~g}, 1.73 \mathrm{mmol}, 1$ eq) in a $250 \mathrm{~mL}$ round bottom flask. This solution was cooled in an ice bath while stirring. A solution of $\mathrm{NaNO}_{2}(136.1 \mathrm{mg}, 1.9 \mathrm{mmol}, 1.1 \mathrm{eq})$ dissolved in $1 \mathrm{~mL}$ of cold water in an Eppendorf tube was added to a $5 \mathrm{~mL}$ syringe with a 4 inch $\mathrm{x} 22$ gauge needle which was clamped above the reaction flask, leading to a gravity assisted dropwise addition. The reaction was stirred at $0{ }^{\circ} \mathrm{C}$ for $1.5 \mathrm{hrs}$. Phloroglucinol ( $76 \mathrm{mg}, 0.59 \mathrm{mmol}, 0.34 \mathrm{eq}$ ) was dissolved in a minimal amount of cold $5 \mathrm{M} \mathrm{NaOH}(1 \sim 2 \mathrm{ml}))$ and added dropwise to the reaction. $5 \mathrm{M} \mathrm{NaOH}$ was added until the $\mathrm{pH}$ was basic as indicated by $\mathrm{pH}$ paper, at which point the ice bath was removed. The $\mathrm{pH}$ was maintained at $\sim 11$ (dark blue on $\mathrm{pH}$ strip) by addition of $5 \mathrm{M} \mathrm{NaOH}$ as necessary. The reaction was allowed to stir overnight. Cold 100\% ethanol $(200 \mathrm{~mL})$ was added to the reaction, which was neutral at this point, as determined by $\mathrm{pH}$ paper. $1.2 \mathrm{M} \mathrm{HCl}$ was added until the solution was acidic as indicated by $\mathrm{pH}$ paper. The reactions flask was placed in a freezer for at least 24 hours until a dark red/brown precipitate was observed. The precipitate was filtered through a Hirsch funnel to provide the crude Yariv reagent $\mathbf{4}$ as a glossy red, sticky powder which clumped together. This solid was allowed to air dry for a few hours, at which point it had hardened in to a solid mass which became a powder when crushed. The powder was transferred to a pre-weighed scintillation vial and dried in a vacuum oven with heat on at a low setting for 24 hours. This crude product $(0.39 \mathrm{~g}, 0.4 \mathrm{mmol})$, was obtained in $72 \%$ yield. Some of this material was further purified twice using the redissolution - reprecipitation protocol reported in the SI: $0.27 \mathrm{~g}$ of the crude product was reprecipitated from $20 \mathrm{~mL}$ of water and $150 \mathrm{~mL}$ of ethanol to give $0.16 \mathrm{~g}$ of $\beta \mathrm{DFuc} \mathrm{R} 1 \mathrm{X}$ product (59\%). The second redissolution - reprecipitation with R1X $(0.09 \mathrm{~g})$ from $20 \mathrm{~mL}$ of water and $150 \mathrm{~mL}$ of ethanol provided $0.035 \mathrm{~g}$ of $\beta$ DFuc R2X $(41 \%) .{ }^{1} \mathrm{H}$ NMR (600 MHz, DMSO) $\delta$ 15.94,15.89, 15.11 and $15.08(\mathrm{~s}, 3 \mathrm{H}), 7.65(\mathrm{~d}, 6 \mathrm{H}), 7.15(\mathrm{~d}, 6 \mathrm{H})$, $5.18(\mathrm{~d}, J=5.2 \mathrm{~Hz}, 3 \mathrm{H}), 4.90(\mathrm{~d}, J=7.6 \mathrm{~Hz}, 3 \mathrm{H}), 4.84(\mathrm{~d}, J=5.8 \mathrm{~Hz}, 3 \mathrm{H}), 4.57$ (d, $J=4.9 \mathrm{~Hz}$, $3 \mathrm{H}), 3.81$ (q, $J=6.6 \mathrm{~Hz}, 3 \mathrm{H}), 3.56(\mathrm{~m}, 3 \mathrm{H}), 3.50$ (t, $J=4.3 \mathrm{~Hz}, 3 \mathrm{H}), 3.44(\mathrm{~m}, 3 \mathrm{H}), 1.18$ (d, $J=$ $6.4 \mathrm{~Hz}, 9 \mathrm{H}) .{ }^{13} \mathrm{C}$ NMR $(151 \mathrm{MHz}$, DMSO) $\delta 178.04,156.83,136.29,128.76,118.95,117.77$, $101.12,73.87,71.41,70.84,70.41,17.09$ 


\section{Synthesis of $\alpha$-L-Fucosyl Yariv reagent (5)}

A Parr shaker bottle was charged with 4-nitrophenyl $\alpha$-L-fucopyranoside ( $1 \mathrm{~g}, 3.38 \mathrm{mmol})$ and methanol $(250 \mathrm{~mL})$ and a stir bar were added to the bottle. The mixture was stirred while sparging for 20 minutes with $\mathrm{N}_{2}$ introduced via a needle. $10 \% \mathrm{Pd} / \mathrm{C}$ (36 mg) was added to the Parr bottle, which was put on a Parr shaker and shaken under $40 \mathrm{psi} \mathrm{H}_{2}$ for 7 hours. TLC showed complete conversion (2:1 Dichloromethane /Isopropyl alcohol). The solution was then filtered through Celite into a $1000 \mathrm{~mL}$ flask and then concentrated in vacuo to about $100 \mathrm{~mL}$ and transferred into a $250 \mathrm{~mL}$ preweighed flask and concentrated in vacuo and placed under high vacuum. The amino sugar was obtained as a pale yellow/clear crystalline solid $(0.9 \mathrm{~g}, 3.35$ mmol, $99 \%$ ). This material was directly used in the next step. ${ }^{1} \mathrm{H}$ NMR (400 MHz, DMSO) $\delta$ $6.74(\mathrm{~d}, 2 \mathrm{H}), 6.49(\mathrm{~d}, 2 \mathrm{H}), 5.08(\mathrm{~d}, J=3.5 \mathrm{~Hz}, 1 \mathrm{H}), 4.68(\mathrm{~d}, 1 \mathrm{H}), 4.68(\mathrm{~s}, 2 \mathrm{H}), 4.65(\mathrm{~s}, 1 \mathrm{H}), 4.50$ $(\mathrm{d}, J=4.4 \mathrm{~Hz}, 1 \mathrm{H}), 4.00-3.90(\mathrm{~m}, 1 \mathrm{H}), 3.68(\mathrm{dddd}, J=19.7,9.9,6.5,2.8 \mathrm{~Hz}, 2 \mathrm{H}), 3.55(\mathrm{~d}, J=$ $3.8 \mathrm{~Hz}, 1 \mathrm{H}), 1.07(\mathrm{~d}, J=6.5 \mathrm{~Hz}, 3 \mathrm{H})$.

A solution of cold freshly prepared $1.2 \mathrm{M} \mathrm{HCl}(7.5 \mathrm{~mL}, 2.5 \mathrm{eq}$, made by adding $3 \mathrm{~mL}$ of $12.1 \mathrm{M}$ $\mathrm{HCl}$ to $27 \mathrm{~mL}$ of water) was added to 4-aminophenyl $\alpha$-L-fucopyranoside ${ }^{19}$ ( $0.85 \mathrm{~g}, 3.34 \mathrm{mmol}$, $1 \mathrm{eq}$ ) in a $250 \mathrm{~mL}$ round bottom flask. This solution was cooled in an ice bath while stirring. A solution of $\mathrm{NaNO}_{2}(254 \mathrm{mg}, 3.7 \mathrm{mmol}, 1.1 \mathrm{eq})$ dissolved in $1 \mathrm{~mL}$ of cold water in an Eppendorf tube was added to a $5 \mathrm{~mL}$ syringe with a 4 inch $\mathrm{x} 22$ gauge needle which was clamped above the reaction flask, leading to a gravity assisted dropwise addition. The reaction was stirred at $0{ }^{\circ} \mathrm{C}$ for 3 hrs. Phloroglucinol (143 mg, $1.14 \mathrm{mmol}, 0.34 \mathrm{eq}$ ) was dissolved in a minimal amount of cold $5 \mathrm{M} \mathrm{NaOH}(1 \sim 2 \mathrm{ml}))$ and added dropwise to the reaction. $5 \mathrm{M} \mathrm{NaOH}$ was added until the $\mathrm{pH}$ was basic as indicated by $\mathrm{pH}$ paper, at which point the ice bath was removed. The $\mathrm{pH}$ was maintained at $\sim 11$ (dark blue on $\mathrm{pH}$ strip) by addition of $5 \mathrm{M} \mathrm{NaOH}$ as necessary. The reaction was allowed to stir overnight. Cold $100 \%$ ethanol $(200 \mathrm{~mL})$ was added to the reaction, which was neutral at this point, as determined by $\mathrm{pH}$ paper. $1.2 \mathrm{M} \mathrm{HCl}$ was added until the solution was acidic as indicated by $\mathrm{pH}$ paper. The reactions flask was placed in a freezer for at least 24 hours until a dark red/brown precipitate was observed. The precipitate was filtered through a Hirsch funnel to provide the crude Yariv reagent $\mathbf{5}$ as a glossy red, sticky powder which clumped together. This solid was allowed to air dry for a few hours, at which point it had hardened in to a 
solid mass which became a powder when crushed. The powder was transferred to a pre-weighed scintillation vial and dried in a vacuum oven with heat on at a low setting for 24 hours. This crude product $(0.97 \mathrm{~g}, 1 \mathrm{mmol})$, was obtained in 93\% yield. This material was further purified twice using the redissolution - reprecipitation followed by methovaping protocol reported in the SI: $0.97 \mathrm{~g}$ of the crude product was reprecipitated from $20 \mathrm{~mL}$ of water and $180 \mathrm{~mL}$ of ethanol to give $0.52 \mathrm{~g}$ of $\alpha$-L-Fuc R1X product (59\%). The second redissolution - reprecipitation with R2X $(0.5 \mathrm{~g})$ from $20 \mathrm{~mL}$ of water and $180 \mathrm{~mL}$ of ethanol provided $0.35 \mathrm{~g}$ of $\alpha$-L-Fuc R2X (68\%). Methovaping $33.8 \mathrm{mg}$ of R2X using $3 \mathrm{~mL}$ of methanol gave $31.1 \mathrm{mg}$ of R2XM (92\%). ${ }^{1} \mathrm{H} \mathrm{NMR}$ (600 MHz, DMSO) $\delta$ 15.95, 15.90, 15.11 and 15.07 (s, 3H), 7.64 (d, $J=6.5 \mathrm{~Hz}, 6 \mathrm{H}), 7.62$ (d, $6 \mathrm{H}), 5.46(\mathrm{~d}, J=3.2 \mathrm{~Hz}, 3 \mathrm{H}), 4.90(\mathrm{~d}, J=5.7 \mathrm{~Hz}, 3 \mathrm{H}), 4.71(\mathrm{~d}, J=5.2 \mathrm{~Hz}, 3 \mathrm{H}), 4.60(\mathrm{~d}, 3 \mathrm{H}$,$) ,$ $3.92(\mathrm{q}, J=6.7 \mathrm{~Hz}, 3 \mathrm{H}), 3.80(\mathrm{~m}, 6 \mathrm{H}), 3.60(\mathrm{t}, J=3.8 \mathrm{~Hz}, 3 \mathrm{H}), 1.09(\mathrm{~d}, J=6.5 \mathrm{~Hz}, 9 \mathrm{H}) .{ }^{13} \mathrm{C}$ NMR (151 MHz, DMSO) $\delta 178.08,156.71,136.31,128.79,118.99,118.35,98.79,71.84,69.93$, $68.09,67.85,16.95$.

\section{Synthesis of $\beta$-L-Fucosyl Yariv reagent (6)}

A Parr shaker bottle was charged with 4-nitrophenyl $\beta$-L-fucopyranoside (0.8 g, 2.82 mmol) and methanol $(250 \mathrm{~mL})$ and a stir bar were added to the bottle. The mixture was stirred while sparging for 20 minutes with $\mathrm{N}_{2}$ introduced via a needle. $10 \% \mathrm{Pd} / \mathrm{C}$ (35 mg) was added to the Parr bottle, which was put on a Parr shaker and shaken under $40 \mathrm{psi} \mathrm{H}_{2}$ for 7 hours. TLC showed complete conversion (2:1 Dichloromethane /Isopropyl alcohol). The solution was then filtered through Celite into a $1000 \mathrm{~mL}$ flask and then concentrated in vacuo to about $100 \mathrm{~mL}$ and transferred into a $250 \mathrm{~mL}$ preweighed flask and concentrated in vacuo and placed under high vacuum. The amino sugar was obtained as a pale yellow/clear crystalline solid $(0.72 \mathrm{~g}, 2.8$ mmol, $99 \%$ ). This material was directly used in the next step. ${ }^{1} \mathrm{H}$ NMR (600 MHz, DMSO) $\delta$ $6.73(\mathrm{~d}, 2 \mathrm{H}), 6.49$ (d, 2H), $5.03(\mathrm{~d}, 1 \mathrm{H}), 4.76(\mathrm{~d}, 1 \mathrm{H}), 4.67(\mathrm{~s}, 2 \mathrm{H}), 4.55(\mathrm{~d}, J=7.6 \mathrm{~Hz}, 1 \mathrm{H}), 4.47$ $(\mathrm{d}, 1 \mathrm{H}), 3.63(\mathrm{qd}, J=6.4,1.1 \mathrm{~Hz}, 1 \mathrm{H}), 3.48-3.42(\mathrm{~m}, 2 \mathrm{H}), 1.13(\mathrm{~d}, J=6.4 \mathrm{~Hz}, 3 \mathrm{H})$.

A solution of cold freshly prepared $1.2 \mathrm{M} \mathrm{HCl}(8 \mathrm{~mL}, 2.5 \mathrm{eq}$, made by adding $3 \mathrm{~mL}$ of $12.1 \mathrm{M}$ $\mathrm{HCl}$ to $27 \mathrm{~mL}$ of water) was added to 4 -aminophenyl $\beta$-L-fucopyranoside ${ }^{20}(0.72 \mathrm{~g}, 2.8 \mathrm{mmol}, 1$ eq) in a $250 \mathrm{~mL}$ round bottom flask. This solution was cooled in an ice bath while stirring. A solution of $\mathrm{NaNO}_{2}(214 \mathrm{mg}, 3.1 \mathrm{mmol}, 1.1 \mathrm{eq})$ dissolved in $1 \mathrm{~mL}$ of cold water in an Eppendorf 
tube was added to a $5 \mathrm{~mL}$ syringe with a 4 inch $\mathrm{x} 22$ gauge needle which was clamped above the reaction flask, leading to a gravity assisted dropwise addition. The reaction was stirred at $0{ }^{\circ} \mathrm{C}$ for 3 hrs. Phloroglucinol (121 mg, $0.96 \mathrm{mmol}, 0.34 \mathrm{eq}$ ) was dissolved in a minimal amount of cold $2 \mathrm{M} \mathrm{NaOH}(1 \sim 2 \mathrm{ml}))$ and added dropwise to the reaction. $2 \mathrm{M} \mathrm{NaOH}$ was added until the $\mathrm{pH}$ was basic as indicated by $\mathrm{pH}$ paper, at which point the ice bath was removed. The $\mathrm{pH}$ was maintained at $\sim 11$ (dark blue on $\mathrm{pH}$ strip) by addition of $2 \mathrm{M} \mathrm{NaOH}$ as necessary. The reaction was allowed to stir overnight. Cold $100 \%$ ethanol $(200 \mathrm{~mL})$ was added to the reaction, which was neutral at this point, as determined by $\mathrm{pH}$ paper. $2.4 \mathrm{M} \mathrm{HCl}$ was added until the solution was acidic as indicated by $\mathrm{pH}$ paper. The reactions flask was placed in a freezer for at least 24 hours until a dark red/brown precipitate was observed. The precipitate was filtered through a Hirsch funnel to provide the crude Yariv reagent 6 as a glossy red, sticky powder which clumped together. This solid was allowed to air dry for a few hours, at which point it had hardened in to a solid mass which became a powder when crushed. The powder was transferred to a pre-weighed scintillation vial and dried in a vacuum oven with heat on at a low setting for 24 hours. This crude product $(0.71 \mathrm{~g}, 1 \mathrm{mmol})$, was obtained in $80 \%$ yield. This material was further purified twice using the redissolution - reprecipitation followed by methovaping protocol reported in the SI: $0.71 \mathrm{~g}$ of the crude product was reprecipitated from $20 \mathrm{~mL}$ of water and $180 \mathrm{~mL}$ of ethanol to give $0.52 \mathrm{~g}$ of $\beta$-L-Fuc R1X product (73\%). The second redissolution - reprecipitation with $\mathrm{R} 2 \mathrm{X}(0.5 \mathrm{~g})$ from $20 \mathrm{~mL}$ of water and $180 \mathrm{~mL}$ of ethanol provided $0.44 \mathrm{~g}$ of $\beta$-L-Fuc R2X (84\%). Methovaping $31 \mathrm{mg}$ of R2X using $3 \mathrm{~mL}$ of methanol gave $28 \mathrm{mg}$ of R2XM (90\%). ${ }^{1} \mathrm{H}$ NMR (600 MHz, DMSO) $\delta$ 15.94, 15.88, 15.10 and $15.06(\mathrm{~s}, 3 \mathrm{H}), 7.62(\mathrm{~d}, 6 \mathrm{H}), 7.14$ (s, 6H), $5.19(\mathrm{~d}, J=5.0 \mathrm{~Hz}, 3 \mathrm{H}), 4.90(\mathrm{~d}, J=7.6 \mathrm{~Hz}, 3 \mathrm{H}), 4.84$ (s, 1H), 4.57 (s, 1H), 3.80 (dq, $J=14.5$, $6.5 \mathrm{~Hz}, 3 \mathrm{H}), 3.57(\mathrm{t}, 3 \mathrm{H}), 3.51(\mathrm{~s}, 3 \mathrm{H}), 3.45$ (d, 3H), 1.18 (d, $J=6.5 \mathrm{~Hz}, 9 \mathrm{H}) .{ }^{13} \mathrm{C}$ NMR $(151$ MHz, DMSO) $\delta 178.08,156.85,136.33,128.81,118.97,117.82,101.16,73.87,71.41,70.84$, $70.40,17.06$.

\section{Acknowledgments}

This work was supported by the National Science Foundation (CHE1607554). Drs. Tun-Li Shen and Russell Hopson are thanked for their assistance with mass spectrometry and NMR spectroscopy, respectively. 


\section{References}

1. Chabre, Y. M.; Roy, R., Multivalent glycoconjugate syntheses and applications using aromatic scaffolds. Chem Soc Rev 2013, 42 (11), 4657-708.

2. Pereira, A. M.; Pereira, L. G.; Coimbra, S., Arabinogalactan proteins: rising attention from plant biologists. Plant Reprod 2015, 28 (1), 1-15.

3. Gollner, E. M.; Gramann, J. C.; Classen, B., Antibodies against Yariv's reagent for immunolocalization of arabinogalactan-proteins in aerial parts of Echinacea purpurea. Planta Med 2013, $79(2), 175-80$.

4. Trifunović-Momčilov, M.; Tadić, V.; Petrić, M.; Paunovic, D.; Jevremovic, S.; Subotic, A., Quantification of arabinogalactan proteins during in vitro morphogenesis induced by $\beta$-d-glucosyl Yariv reagent in Centaurium erythraea root culture. Acta Physiologiae Plantarum 2014, 36, 1187-1195.

5. Komalavilas, P.; Zhu, J. K.; Nothnagel, E. A., Arabinogalactan-proteins from the suspension culture medium and plasma membrane of rose cells. Journal of Biological Chemistry 1991, 266 (24), 15956-15965.

6. $\quad$ Zhong, J.; Ren, Y.; Yu, M.; Ma, T.; Zhang, X.; Zhao, J., Roles of arabinogalactan proteins in cotyledon formation and cell wall deposition during embryo development of Arabidopsis. Protoplasma 2011, 248 (3), 551-63.

7. Yariv, J.; Rapport, M. M.; Graf, L., The interaction of glycosides and saccharides with antibody to the corresponding phenylazo glycosides. Biochem $J$ 1962, 85, 383-8.

8. Ganjian, I.; Basile, D. V., Reductive syntheses of p-aminophenyl-beta-D-glucoside and its conversion to beta-glucosyl Yariv reagent. Anal Biochem 1997, 246 (1), 152-5.

9. $\quad$ Basile, D. V.; Ganjian, I., $\beta$-d-Glucosyl and $\alpha$-d-Galactosyl Yariv Reagents: Syntheses from pNitrophenyl-d-glycosides by Transfer Reduction Using Ammonium Formate. Journal of Agricultural and Food Chemistry 2004, 52 (25), 7453-7456.

10. Zhang, J.; Li, M.; Chen, C.; Xu, Y.; Tian, X. Method for preparing $\beta$-glucosyl-yariv reagent from 4-nitrophenyl glucoside. CN101691450B, April 07, 2010.

11. Zhang, J.; Li, M.; Chen, C.; Xu, Y.; Tian, X. One-step process for preparation of $\beta$-glucosylYariv reagent. CN101525358A, Sep 09, 2009.

12. E.F. Woods, G. G. L., M.A. Jermyn, The Self-Association of Glycosyl Phenylazo Dyes (Yariv Antigens). Australian Journal of Chemistry 1978, 31 (10), 2225-2238.

13. Chan, Y. T.; Moorefield, C. N.; Newkome, G. R., Synthesis, characterization, and self-assembled nanofibers of carbohydrate-functionalized mono- and di(2,2':6',2"-terpyridinyl)arenes. Chem Commun (Camb) 2009, (45), 6928-30.

14. Lee, D. W.; Kim, T.; Park, I. S.; Huang, Z.; Lee, M., Multivalent nanofibers of a controlled length: regulation of bacterial cell agglutination. $J$ Am Chem Soc 2012, 134 (36), 14722-5.

15. Wang, K. R.; An, H. W.; Wu, L.; Zhang, J. C.; Li, X. L., Chiral self-assembly of lactose functionalized perylene bisimides as multivalent glycoclusters. Chem Commun (Camb) 2012, 48 (45), 5644-6.

16. Yu, G.; Ma, Y.; Han, C.; Yao, Y.; Tang, G.; Mao, Z.; Gao, C.; Huang, F., A sugar-functionalized amphiphilic pillar[5]arene: synthesis, self-assembly in water, and application in bacterial cell agglutination. J Am Chem Soc 2013, 135 (28), 10310-3.

17. Capicciotti, C. J.; Mancini, R. S.; Turner, T. R.; Koyama, T.; Alteen, M. G.; Doshi, M.; Inada, T.; Acker, J. P.; Ben, R. N., O-Aryl-Glycoside Ice Recrystallization Inhibitors as Novel Cryoprotectants: A Structure-Function Study. ACS Omega 2016, 1 (4), 656-662.

18. Peyrot, C.; Vivès, T.; Legentil, L.; Lemiègre, L.; Daniellou, R., Microwave-Assisted Reduction of Nitroarenes by Aminothiophenol/dithiotreitol. ChemistrySelect 2017, 2 (18), 5214-5217. 
19. Kumar, A. B.; Hong, X.; Yi, F.; Wood, T.; Gelb, M. H., Tandem mass spectrometry-based multiplex assays for alpha-mannosidosis and fucosidosis. Mol Genet Metab 2019, 127 (3), 207-211. 20. Lerchen, H.-G.; Baumgarten, J.; Piel, N.; Kolb-Bachofen, V., Lectin-Mediated Drug Targeting: Discrimination of Carbohydrate-Mediated Cellular Uptake between Tumor and Liver Cells with Neoglycoconjugates Carrying Fucose Epitopes Regioselectively Modified in the 3-Position. Angewandte Chemie (International ed. in English) 2000, 38, 3680-3683. 